\title{
Perkembangan Sosial Emosional Anak Usia Dini di Pondok Pesantren Tahfidz Hidayatul Muta'allimin
}

\author{
M. Arif Khoiruddin' ${ }^{1}$, Susiati Alwi ${ }^{2}$ \\ 1, 2 Institut Agama Islam Tribakti Kediri \\ 12arif@iai-tribakti.ac.id, ${ }^{2}$ susiati@iai-tribakti.ac.id
}

\begin{abstract}
Parent plays an important role in children social and emotional development. Most of the parents lay the students education and taking care of the Islamic boarding school from an early age. Children who live in the boarding have a demanding schedule from memorizing, studying, and Islamic practices continually in a long period. This could lead the children to a psychological problem. This research is aimed to know the psychology condition of the children who lived in a boarding house since early age troubled in social and emotional development. The research design and approach is descriptive qualitative. The research setting is Hidayatul Muta'alimin Islamic boarding School Gurah Kabupaten Kediri. Most of the students are children and the advanced program is tahfidz Al-Qur'an. The data sampling is the interview, observation, and some school documents. The research finding shows that no serious psychological problem for children. The social-emotional development of the children is also fine. It is caused by a friendly environment for the children and a free hand of playing on the spare time makes them away from feeling lonely, bored and they are also cheerful although live away from their parents. Moreover, the school management gives an example of how to interact socially to the students in the boarding school.
\end{abstract}

\section{Keywords: Children, Islamic Boarding House, Social Emotional}

\section{Abstrak}

Orang tua mempunyai peranan penting dalam proses perkembangan sosial emosional anak. Banyak orang tua yang memercayakan pendidikan dan pengasuhan anak di pondok pesantren sejak usia dini. Anak yang berada di pondok pesantren dengan aktifitas kegiatan yang sangat padat mulai hafalan, belajar dan praktik-praktik ibadah yang dilakukan secara terus menerus dalam jangka waktu yang lama memungkinkan bagi anak terjadi persoalan psikologis. Penelitian ini dilakukan untuk mengetahui bagaimana kondisi anak yang menetap di pondok pesantren sejak usia dini apakah terdapat persoalan dalam perkembangan sosial emosional. Jenis dan pendekatan dalam penelitian ini menggunakan kualitatif deskriptif. Lokasi penelitian berada di Pondok Pesantren Hidayatul Muta'alimin Gurah Kabupaten Kediri yang mayoritas santrinya adalah anak usia sekolah dasar dengan program unggulannya tahfidz Al-Qur'an. Sumber data diperoleh melalui wawancara, 
pengamatan dan beberapa arsip domentasi pondok pesantren. Hasil penelitian menunjukkan tidak terdapat persoalan psikologis yang berarti bagi anak yang berada di pondok pesantren, perkembangan sosial emosional anak juga cukup baik. Hal ini didukung oleh lingkungan yang ramah bagi anak, kebebasan bermain di luar jam kegiatan membuat mereka tidak merasa kesepian, bosan dan ceria meskipun jauh dari orang tua serta pengurus memberikan contoh cara berinteraksi sosial kepada santri di pondok pesantren.

Kata kunci: Anak, Pondok Pesantren, Sosial Emosional

\section{Pendahuluan}

Pendidikan saat ini harus memerhatikan perkembangan anak secara menyeluruh termasuk perkembangan sosial, emosional, moral dan perkembangan akademik. Kemampuan sosial emosional harus ditanamkan sejak usia dini secara sistematis dan terprogram. Perilaku yang tidak diinginkan dapat terjadi pada anak akibat tidak terpenuhinya kebutuhan anak yang sedang dalam masa pertumbuhan dan perkembangan. Hal ini berakibat tidak hanya memperlambat perkembangan sosial emosional, tetapi juga berdampak negatif pada perkembangan moral anak. ${ }^{1}$

Perkembangan sosial-emosional adalah istilah yang digunakan untuk menggambarkan kemampuan anak yang sedang tumbuh dan berkembang dalam membentuk hubungan dengan orang lain menggunakan emosi secara produktif. ${ }^{2}$ Dalam perkembangan sosial emosional juga berhubungan dengan perkembangan kognitif, fisik, dan moral yang memiliki posisi penting dalam pembentukan kepribadian dan karakter bagi anak.

Center on the Social Emotional Foundations for Early Learning (CSEFEL) mendefinisikan perkembangan sosial dan emosional awal sebagai pengembangan anak sejak usia lahir hingga lima tahun untuk membentuk dan menjalin hubungan dengan orang dewasa, teman sebaya. Kemampuan sosial dan emosional dimulai sejak lahir dan pengalaman awal dapat memengaruhi bagaimamana anak mulai memahami diri mereka sendiri. Misalnya, ketika kebutuhan bayi dipenuhi oleh orang tua secara konsisten, anak akan lebih mampu mengatur emosi, lebih memerhatikan lingkungan mereka, dan mengembangkan hubungan yang positif. Ketika anak terus mengembangkan

\footnotetext{
${ }^{1}$ Kayhan Bozgün and Kemal Baytemir, "Sosyal-Duygusal Ve Ahlaki Gelişim Ölçeğinin (Sdago) Türkçeye Uyarlanmasi: Geçerlik Ve Güvenirlik Çalişmasi," Adaptation of Social-Emotional and Character Development Scale Into Turkish: Validity And Reliability Study. 14, no. 1 (January 2019): 143, https://doi.org/10.7827/TurkishStudies.14754.

2 Timothy S. Hartshorne and Nancy Salem-Hartshorne, "Social/Emotional.," in CHARGE Syndrome., Genetic Syndromes and Communication Disorders Series. (San Diego, CA, US: Plural Publishing Inc., 2011), 205.
} 
keterampilan sosial dan emosional, mereka memperoleh kepercayaan diri dan kompetensi yang dibutuhkan untuk membangun hubungan lintas lingkungan, memecahkan masalah, dan mengatasi tantangan. ${ }^{3}$

Perkembangan sosial emosional anak menurut Suyadi sejatinya saling berkaitan dan tidak dapat dipisahkan. Maksudnya jika membahas perkembangan sosial anak maka harus membahas perkembangan emosinya, begitu pula sebaliknya. Setiap anak pada usia dini tidak semuanya berhasil melewati perkembangan sosial emosionalnya karena berbagai kendala mungkin saja terjadi. ${ }^{4}$

Perkembangan sosial emosional anak secara langsung memengaruhi dalam proses pembelajaran dan diperlukan dukungan lebih banyak bagi anak dari berbagai pihak. Anak yang memiliki hubungan teman sebaya yang positif dan baik di kelas cenderung mempelajari perilaku positif seperti kompetensi sosial, motivasi, perhatian, dan ketekunan. Di sisi lain anak masalah dengan hubungan teman sebaya cenderung mengalami penerimaan teman yang lebih rendah dan memiliki berbagai sifat yang menyusahkan seperti hiperaktif dan ketidakmampuan berkonsentrasi. Anak seperti ini dibandingkan dengan mereka yang memiliki hubungan teman yang baik, memiliki tingkat agresi yang lebih tinggi dan tingkat akomodasi sosial dan prestasi akademik yang jauh lebih rendah. ${ }^{5}$

Perkembangan sosial emosional anak pada usia dini berpengaruh besar terhadap kehidupan selanjutnya pada saat mereka tumbuh dewasa. Anak yang berusia 6-11 tahun mengalami fase pertumbuhan dan perkembangan tidak hanya secara fisik saja tetapi juga mental sosialnya. Pada usia ini kesempatan orang tua untuk menstimulasi pertumbuhan dan perkembangan anak, pada masa ini juga sangat rentan terhadap gangguan pertumbuhan dan perkembangan terutama persoalan psikologis. ${ }^{6}$

Perkembangan yang positif bagi anak sangat penting karena akan menjadikan anak tersebut mampu melewati masa transisi tanpa ada kendala, dapat bertingkah laku yang sesuai dengan norma sosial dan dapat memahami arti hidup. Perkembangan sosial

\footnotetext{
3 Tamara G. Halle and Kristen E. Darling-Churchill, "Review of Measures of Social and Emotional Development," Journal of Applied Developmental Psychology $45 \quad$ (July 2016): 8, https://doi.org/10.1016/j.appdev.2016.02.003.

4 Muhammad Shaleh Assingkily and Mikyal Hardiyati, "Analisis Perkembangan Sosial-Emosional Tercapai Dan Tidak Tercapai Siswa Usia Dasar," Al-Aulad: Journal of Islamic Primary Education 2, no. 2 (July 5, 2019): 22, https://doi.org/10.15575/al-aulad.v2i2.5210.

${ }^{5}$ Mona Alzahrani, Manal Alharbi, and Amani Alodwani, "The Effect of Social-Emotional Competence on Children Academic Achievement and Behavioral Development," International Education Studies 12 (November 29, 2019): 144, https://doi.org/10.5539/ies.v12n12p141.

6 Anderson, Carolynne Shinn, and Fullilove Mindy T, "The Effectiveness of Early Childhood Development Programs," American Journal of Preventive Medicine 24 (2003): 32.
} 
anak merupakan pembelajaran tentang nilai-nilai, pengetahuan dan keterampilan anak yang berhubungan dengan orang lain secara efektif dan memberikan kontribusi positif terhadap keluarga, sekolah maupun lingkungan atau masyarakat. ${ }^{7}$

Pada masa awal anak yang terpenting adalah mendapatkan pengalaman dan latihan untuk menjadi anggota kelompok. Masa ini disebut sebagai masa pra kelompok. Dengan meningkatnya hubungan anak dengan teman sebaya dari tahun ke tahun. Anak tidak hanya banyak bermain tetapi juga banyak berbicara merupakan dasar sosialisasi. ${ }^{8}$

Peran orang tua pada masa pertumbuhan dan perkembangan anak sangat penting sebab orang tua sebagai peletak dasar pendidikan, sikap dan keterampilan hidup anak seperti menanamkan kebiasaan dan aturan, mengajarkan budi pekerti, memberikan kasih sayang, mengajari sopan santun dan sebagainya. Dengan demikian anak akan menunjukkan stabilitas sosial-emosional, peningkatan hasil belajar, perbaikan sikap dan kedisiplinan jika orang tua secara aktif terlibat dalam proses pengasuhan dan pendidikan termasuk mengenalkan lingkungan keluarga dan masyarakat sejak usia dini, karena lingkungan mempunyai pengaruh besar terhadap pertumbuhan, perkembangan serta kepribadian anak. ${ }^{9}$

Orang tua tidak menginginkan masa depan anak suram, tetapi mereka ingin anak hidup bahagia, taat dan berbakti, berakhlak baik dan apapun yang positif bagi anak. Banyak cara yang dilakukan orang tua untuk mencapai keinginan tersebut, di antaranya dengan mempercayakan pendidikan dan pengasuhan anak di pondok pesantren. ${ }^{10}$ Anak yang tinggal di pondok pesantren sebagian besar atas keinginan dan kemauan orang tua, sehingga dalam prosesnya banyak anak yang belum sepenuhnya bisa menerima segala konsekuensi kegiatan dan peraturan yang ada.

Faktor yang melatarbelakangi orang tua mempercayakan pendidikan dan pengasuhan anak di pondok pesantren bahkan sejak usia dini. Diantaranya orang tua menginginkan anaknya di pondok pesantren tujuannya agar mereka bisa mandiri dan dapat memperdalam ilmu agama, ada orang tua yang memang sibuk bekerja sehingga tidak sempat mendidik dan mengasuh anaknya, ada orang tua yang bekerja keluar

\footnotetext{
7 Gill Kirk and Jenny Jay, "Supporting Kindergarten Children's Social and Emotional Development: Examining the Synergetic Role of Environments, Play, and Relationships," Journal of Research in Childhood Education 32, no. 4 (October 2, 2018): 474, https://doi.org/10.1080/02568543.2018.1495671.

${ }^{8}$ Elizabeth B. Hurlock, Chiled Development (Tokyo: Mc. Graw Hill. Inc, 1978), h. 250.

${ }^{9}$ Ujam Jaenudin, Psikologi Kepribadian (Bandung: CV Pustaka Setia, 2012), 74.

${ }^{10}$ Dedi Supriatna, "Motivasi Orang Tua Memilih Pondok Pesantren Untuk Anaknya," Intizar 24, no. 1 (January 1, 1970): 1, https://doi.org/10.19109/intizar.v24i1.1951.
} 
negeri karena kebutuhan ekonomi kemudian anaknya ditempatkan di pondok pesantren, ada orang tua yang bercerai kemudian terpaksa anak dititipkan pondok pesantren. ${ }^{11}$

Tanggung jawab dan dukungan orang tua tidak lepas begitu saja saat anak berada di pondok pesantren meskipun peran mereka sudah digantikan oleh pengasuh dan tenaga pengajar, tetapi dukungan orang tua sangat diperlukan agar anak lebih termotivasi dan percaya diri belajar di pesantren. Dukungan yang diberikan orang tua tidak sekedar dalam bentuk psikologis saja namun non-psikologis diperlukan, dengan demikian anak tetap merasa diperhatikan dan mendapat kasih sayang dari orang tua. ${ }^{12}$

Kemudian hubungan guru dan siswa juga memainkan peran penting dalam memperkuat kemampuan berperilaku anak yang positif. Banyak peneliti telah mencatat bahwa hubungan guru dan siswa yang dekat berfungsi mengontrol anak yang terlibat dalam perilaku bermasalah dan membantu dalam interaksi sosial anak. Begitu sebaliknya jika hubungan guru dan siswa tidak baik, guru tidak dapat mengontrol perilaku negatif anak yang berinteraksi sosial. ${ }^{13}$

Kemampuan mengontrol perasaan diri sendiri dan kemampuan memahami perasaan orang lain merupakan contoh khusus dalam kompetensi emosional. Tindakan yang desain untuk menilai kompetensi emosional anak perlu dilakukan oleh orang tua atau guru untuk mengamati kemampuan anak dalam menunjukkan kasih sayang kepada orang yang dikenalnya, memahami perasaan orang lain saat mereka bahagia, sedih atau marah, serta mengartikulasikan keadaan emosional mereka sendiri. ${ }^{14}$

Perkembangan sosial emosional anak tergantung pada individu anak, peran orang tua, lingkungan masyarakat. Ada kaitan yang erat antara keterampilan bergaul dengan masa bahagia di masa anak-anak. Kemampuan anak untuk menyesuaikan diri dengan lingkungan, penerimaan lingkungan serta pengalaman-pengalaman positif lain selama melakukan aktifitas sosial merupakan modal dasar yang sangat penting untuk satu kehidupan sukses dan menyenangkan di masa yang akan datang. Perkembangan

${ }^{11}$ Siti Mumun Muniroh, "Psikologi Santri Usia Dini," JURNAL PENELITIAN 11, no. 1 (January 30, 2015): 48, https://doi.org/10.28918/jupe.v11i1.418.

12 Rosyidah Umpu Malwa, "Dukungan Sosial Orangtua Dengan Motivasi Belajar Siswa Putra Tahfidz AlQur'an," Psikis: Jurnal Psikologi Islami 3, no. 2 (February 5, 2018): 138, https://doi.org/10.19109/psikis.v3i2.1758.

13 Alzahrani, Alharbi, and Alodwani, "The Effect of Social-Emotional Competence on Children Academic Achievement and Behavioral Development," 146.

${ }^{14}$ Halle and Darling-Churchill, "Review of Measures of Social and Emotional Development," 10. 
sosial di lingkungan keluarga juga dipengaruhi oleh beberapa faktor, yaitu: status keluarga, keutuhan keluarga, sikap dan kebiasaan orang tua. ${ }^{15}$

Pola komunikasi keluarga dan perkembangan emosi anak pada keluarga dapat menentukan keberhasilan proses sosialisasi pada anak. Sebagaimana Yuli Setyowati menjelaskan dalam penelitiannya bahwa sistem nilai budaya Jawa yang disosialisasikan kepada anak, banyak memberikan pengaruh positif terhadap pembentukan dan perkembangan emosi anak. Dalam hal ini adalah sistem nilai yang berhubungan dengan kualitas-kualitas emosi anak, antara lain nilai-nilai tentang sikap hormat, tata krama atau sopan-santun, kesabaran dalam menyelesaikan masalah masalah, serta toleransi yang menjadi dasar terbentuknya sikap empati anak. Dengan demikian, anak-anak akan tumbuh dan berkembang menjadi pribadi yang cerdas, baik secara intelektual maupun emosional, yang akhirnya menjadi dasar bagi kecerdasan yang lain, yaitu kecerdasan sosial, moral, dan spiritual. ${ }^{16}$

Pondok Pesantren Hidayatul Muta'allimin menerima santri mulai usia dini diharapkan dapat menyediakan lingkungan yang ramah dan positif bagi anak dengan pembiasaan akhlak dan perilaku taat dalam beribadah serta hubungan sosial. Menurut pengasuh pondok lingkungan negatif dapat masuk dan mempengarui dalam kehidupan anak sejak usia dini, untuk mengantisipasi dan menghindari pengaruh negatif tersebut terutama dalam bentuk kebiasaan anak sehari-hari. Program unggulan di pondok ini yaitu tahfidz Al-Qur'an untuk mempersiapkan generasi muslim yang Hamilil Quran yaitu hafal lafadh, makna dan mampu mengamalkan kandungan ajarannya dan berilmu pengetahuan. ${ }^{17}$

Padatnya aktifitas di pondok pesantren dari bangun tidur sampai menjelang tidur lagi bagi anak usia dini seperti beratnya hafalan kemudian dipaksa untuk menghafal, lelahnya mengikuti proses belajar pendidikan formal dan diniyah dengan peraturan pondok yang ketat, praktik ibadah yang dilakukan secara terus menerus dalam jangka waktu yang lama menjadikan malas dan bosan sehingga hak bermain anak berkurang.

Banyak orang tua, pengasuh anak bisa jadi pengurus pondok pesantren mengesampingkan masalah ini, padahal perkembangan sosial emosional merupakan

\footnotetext{
${ }^{15}$ Farida Mayar, "Perkembangan Sosial Anak Usia Dini sebagai bibit untuk Masa Depan Bangsa," Al-Ta lim Journal 20, no. 3 (November 21, 2013): 459-64, https://doi.org/10.15548/jt.v20i3.43.

${ }^{16}$ Yuli Setyowati, "Pola Komunikasi Keluarga dan Perkembangan Emosi Anak (Studi Kasus Penerapan Pola Komunikasi Keluarga dan Pengaruhnya terhadap Perkembangan Emosi Anak pada Keluarga Jawa),” Jurnal ILMU KOMUNIKASI 2, no. 1 (December 5, 2013), https://doi.org/10.24002/jik.v2i1.253.

${ }^{17}$ Wawancara dengan Mahfud, M.Pd.I., Pengasuh Pondok Pesantren Hidayatul Mutaallimin, 25 Agustus 2017
} 
faktor sangat penting tanpa disadari jika perkembangan emosi anak terganggu maka perkembangan sosial ikut terpengaruh. Anak yang memiliki masalah perkembangan sosial emosional kecenderungan memiliki hambatan besar dalam hal akademik, pertemanan, tingkah laku, penyesuaian sosial dan berisiko tersisih secara sosial, pemalu, kesepian dan lain sebagainya. ${ }^{18}$

Penelitian perkembangan sosial emosional anak usia dini di lembaga formal maupun pondok pesantren sudah banyak dilakukan, namun berdasarkan hasil pelacakan yang berkaitan dengan perkembangan sosial emosional anak usia dini di pondok pesantren tahfidz belum banyak dilakukan, hal ini penting mengingat beratnya hafalan, padatnya aktifitas belajar dan ketatnya peraturan pondok pesantren memungkinkan terjadi persoalan dan gangguan psikologis terutama perkembangan sosial emosionalnya.

Berangkat dari permasalahan tersebut diharapkan penelitian ini dapat memberikan kontribusi bagi pengasuh dan pengajar di pondok pesantren tentang bagaimana mendidik dan mengasuh anak-anak dengan tetap memperhatikan perkembangan sosial dan emosional santri. Bagi orang tua santri dapat memberikan pemahaman dan informasi berharga saat memondokkan anak sejak usia dini agar tetap memperhatikan faktor psikologis dan non-psikologis anaknya.

\section{Metode Penelitian}

Jenis dan pendekatan yang digunakan dalam penelitian ini menggunakan kualitatif deskriptif, yaitu menjelaskan perkembangan sosial emosional anak usia dini yang menetap di pondok pesantren. Kehadiran peneliti di lapangan disadari oleh informan dan sebagai instrumen utamanya adalah peneliti sendiri. Lokasi penelitian di Pondok Pesantren Hidayatul Muta'alimin Gurah Kabupaten Kediri yang menyelenggarakan program tahfidz Al-Qur'an khusus mulai anak usia dini. Sumber data diperoleh melalui wawancara dengan pengasuh pondok pesantren, beberapa pengurus pondok dan para santri. Pengamatan dilakukan melalui aktifitas kegiatan sehari-hari santri dan beberapa arsip domentasi pondok pesantren. Proses pengumpulan data dan analisis melalui reduksi, penyajian data dan menarik kesimpulan.

${ }^{18}$ Rini Hildayani, Psikologi Perkembangan Anak (Jakarta: Universitas Terbuka, 2011). 


\section{Aktifitas Anak Di Pondok Pesantren}

Pondok Pesantren Hidayatul Muta'allimin memiliki santri mayoritas berusia 512 tahun. Pondok pesantren ini dalam aktifitas kegiatan belajar mengajar terbilang cukup padat mulai dari shubuh sampai setelah isya. Setelah salat shubuh berjamaah santri diwajibkan setoran hafalan Al-Qur'an pada guru masing-masing sesuai target juz yang sudah ditentukan dalam kurikulum pondok pesantren, setoran binnadhar khusus bagi santri yang belum menghafal. Pesantren ini memiliki lembaga pendidikan formal mulai dari PAUD, TK, MI, dan MTs yang berada dalam pondok pesantren. Sedangkan Madrasah Aliyah/SMA mulai dirintis. Madrasah Diniyah (madin) sebagai pelengkap dan kajian untuk memperdalam ilmu agama Islam.

Pada pukul 07.00 WIB sampai dhuhur santri sudah beraktifitas di sekolah formal milik pondok pesantren mulai dari tingkat PAUD, TK, MI dan MTs. Setelah salat dhuhur santri melanjutkan kegiatan sekolah diniyah (madin) untuk memperdalam ilmu agama Islam. Setelah salat ashar santri mengikuti kegiatan Taman Pendidikan AlQur'an (TPQ). Setelah salat magrib kegiatan pendalaman ilmu Qira'at dan ba'da Isya materi kitab Kuning dan belajar bersama. Padatnya kegiatan belajar mengajar mulai setelah subuh sampai setelah isya ada jeda waktu istirahat bagi santri. Jeda waktu tersebut biasanya digunakan santri melakukan aktifitas di luar kegiatan belajar seperti bermain-main dengan temannya, ada yang menonton televisi beramai-ramai, saling mengobrol dan istirahat tidur.

Ditinjau dari latar belakang orang tua santri di pondok pesantren baik sekolah formal maupun non formal mereka berasal dari berbagai latar belakang keluarga. Ada yang berasal dari keluarga atau orang tua yang menginginkan anak di pondok pesantren agar bisa mandiri dan memperdalam ilmu agama. Ada pula yang orangtuanya sibuk bekerja sehingga tidak sempat mendidik dan mengasuh anaknya kemudian dipondokkan, ada orang tuanya keluar negeri dan ada orang tua yang bercerai sehingga terpaksa anak dititipkan pondok pesantren. Di pesantren ini juga ada santri kalong yang berasal dari desa sekitar pondok hanya mengikuti kegiatan belajar mengajar di pondok tetapi tidak menetap dan mereka tinggal di rumah masing-masing.

Santri yang berasal dari latar belakang orang tua yang beragam seperti pola pengasuhan, pendidikan, dan lingkungan anak sebelum berada di pondok sedikit banyak berpengaruh terhadap perilaku santri. Untuk mengontrol dan mengarahkan perilaku atau karakter santri yang beragam, maka diterapkan aturan pondok bagi santri yang tertuang dalam tata tertib dan kebijakan pondok pesantren. Peraturan pondok yang 
sudah ditetapkan tersosialisasikan dengan baik ke pengurus sebagai kepanjangan tangan pengasuh pondok pesantren dalam menegakkan aturan dan pengawasan santri dalam kegiatan sehari-hari, dengan demikian tidak terjadi tumpang tindih dan bisa berjalan secara efektif.

Pertemuan rutin pengasuh dan pengurus pondok juga dilakukan sebagai bagian dari evalusi. Informasi yang didapatkan peneliti melalui wawancara dengan pengasuh dan pengurus pondok diperkuat dengan observasi di lapangan. Pada jam kegiatan aktifitas belajar, pengurus sangat disiplin menerapkan peraturan tersebut seperti santri wajib mengaji dan setoran al-Qur'an, keaktifan salat berjamaah, sekolah diniyah dan kegiatan keagamaan lainnya. Pada jam istirahat atau di luar kegiatan belajar santri bebas bermain dengan temannya namun tetap berada dalam pengawasan pengurus.

\section{Perkembangan Sosial Emosional Anak di Pondok Pesantren}

Meskipun jadwal kegiatan di pondok pesantren cukup padat, perkembangan psikologis santri menunjukkan perkembangan yang positif dan tidak mengalami persoalan atau kendala yang berarti, baik secara sosial maupun emosional. Hal ini dapat dilihat dari hubungan pertemanan, interaksi sosial dengan teman sebaya maupun dengan pengurus pondok, penyesuaian diri dengan lingkungan pondok pesantren dan kegiatan belajar mengajar. Santri juga tidak merasa kesepian dan bosan, mereka merasa senang, gembira menunjukkan wajah keceriaan terutama saat bermain bersama teman-teman sebaya meskipun jauh dari rumah dan orang tuanya. Umumnya hanya santri baru yang butuh proses penyesuaian dengan lingkungan pondok sekitar 1-2 bulan masih mengalami sedikit kendala, tetapi setelah itu sudah mulai beradaptasi.

Perkembangan sosial emosional yang positif bagi anak sangat penting untuk membentuk perilaku, memahami arti kehidupan serta mampu melewati masa transisi dari anak-anak ke dewasa tanpa kendala apapun. Kemampuan sosial emosional ini mutlak diperlukan dalam menghadapi lingkungan keluarga dan masyarakat. Suasana lingkungan yang ramah dan nyaman membuat anak akan tumbuh dan berkembang dengan ceria dan semangat juga kemampuan berpikirnya berkembang dengan baik. ${ }^{19}$

Pengasuh dan pengurus Pondok Pesantren Hidayatul Muta'allimin juga memperhatikan perkembangan sosial emosional santrinya. Hal ini dapat dilihat santri yang berada di pondok pesantren tidak hanya dituntut untuk mengikuti pelajaran dan

19 M. Arif Khoiruddin, "Perkembangan Anak Ditinjau Dari Kemampuan Sosial Emosional," Jurnal Pemikiran Keislaman 29, no. 2 (December 24, 2018): 425, https://doi.org/10.33367/tribakti.v29i2.624. 
hafalan saja, namun santri didorong dan diberikan kesempatan bebas untuk bermain, berinteraksi dengan santri lainnya serta mengupayakan lingkungan pondok pesantren yang ramah bagi anak-anak. Kebebasan bermain yang diberikan tetap terkontrol dan diatur melalui jadwal kegiatan sehari-hari santri termasuk di dalamnya ada waktu khusus bermain bagi anak.

Di luar jadwal kegiatan belajar mengajar santri banyak melakukan aktifitas bermain sesama santri yang lain seperti permainan sodor, petak umpet dan beberapa permainan tradisional lainnya yang biasa dilakukan sesuai dengan usia mereka. Saat jam bermain santri sudah habis dan menjelang masuk kegiatan aktifitas belajar mengajar, pengurus pondok berperan aktif mengingatkan dan mengarahkan santri menaati peraturan dan jadwal kegiatan yang ada. Berdasarkan pengamatan anak-anak yang bermain, berinteraksi sosial melalui obrolan, candaan dan menonton televisi secara beramai-ramai dengan sesama santri dari wajah mereka terlihat ceria, sangat senang dan gembira.

Permainan tradisional yang jarang dilakukan anak-anak saat ini tetapi sering dilakukan santri di pondok pesantren seperti petak umpet, kelereng, gobak sodor dan beberapa permainan tradisional lainnya secara fisik maupun mental memiliki banyak manfaat dan sangat baik bagi perkembangan dan pertumbuhan anak. Permainan ini bisa melatih otak kanan dan otak kiri sehingga kecerdasan intelektual dan emosional bisa berjalan seimbang. Contoh permainan gobak sodor permainan ini cocok digunakan untuk mengembangkan interaksi sosial anak, anak dapat mengenal dan menghargai teman dan lingkungannya, menghasilkan pengertian dan informasi, memberikan kesenangan dan mengembangkan imajinasi anak. ${ }^{20}$

Wawancara dengan KH. Makhfud selaku pengasuh pondok pesantren yang juga berprofesi sebagai dosen perguruan tinggi di Kediri menjelaskan pentingnya keseimbangan antara kegiatan belajar dan bermain bagi santri yang mayoritas anakanak. Kegiatan bermain dan belajar bagi anak memang tidak dapat dipisahkan. Anak yang hanya belajar saja tanpa diimbangi dengan bermain, mereka cenderung merasa bosan dan jenuh dengan pelajarannnya, ini berdampak pada hubungan sosial anak dengan teman sebaya dan lingkungan sekitar tidak akan terbangun dan terjalin dengan baik. Begitu pula sebaliknya anak yang hanya bermain saja tanpa diimbangi dengan belajar akan merasa kesulitan dalam menerima pelajaran. Bermain dan belajar harus ada

\footnotetext{
${ }^{20}$ I. Nyoman Wardika, "Penerapan Permainan Tradisional untuk mengatasi kejenuhan Belajar PJOK,"
} Journal of Education Action Research 3, no. 3 (2019): 233, https://doi.org/10.23887/jear.v3i3.17377. 
keseimbangan sehingga anak bisa menerima pelajaran dengan baik, mereka tidak merasa jenuh dan bosan juga tidak menghilangkan hak-hak anak untuk bermain. ${ }^{21}$

Peneliti juga menggali informasi dari pengurus pondok, senada dengan apa yang disampaikan kiai Makhfud bahwa santri yang ada di pondok ini pada umumnya tidak merasa kesepian dan bosan terutama saat bermain bersama dengan teman sebayanya meskipun mereka jauh dengan orang tuanya. Yang peneliti amati pada saat santri bermain bersama dengan teman sebayanya menunjukkan kekompakan dan keharmonisan di antara mereka, dalam permainan pasti ada yang menang dan kalah, mereka yang kalah dalam bermain tidak marah dan raut muka penuh dengan keceriaan. Selain memberikan kebebasan bermain, pondok pesantren juga memberikan kesempatan santri menonton televisi yang memang disediakan pondok pesantren di luar jam kegiatan, kegiatan ini dilakukan biasanya secara beramai-ramai. Kebersamaan santri dalam menonton televisi ini secara tidak langsung dapat membentuk jalinan komunikasi dan interaksi sosial antara santri satu dengan yang lainnya.

Banyak penelitian menjelaskan bahwa kemampuan sosial emosional bisa dilatih dan distimulasi salah satunya melalui kegiatan bermain. Permainan yang dilakukan oleh anak-anak mampu melatih memahami perasaan temannya, proses konflik yang terjadi saat interaksi dengan teman sebaya terutama sangat membantu anak untuk memahami orang lain selain dirinya yang memiliki pandangan berbeda dengan dirinya. ${ }^{22}$ Perasaan senang dan mengekspresikan diri tanpa adanya paksaaan bisa didapatkan oleh anak melalui kegiatan bermain bersama teman sebaya atau bersama sekelompok teman, pada anak usia dini kegiatan bermainan dapat memberikan banyak manfaat seperti aspek kognitif, bahasa, motorik terutama perkembangansosial anak. ${ }^{23}$

Kemudian lingkungan pondok pesantren yang ramah dan menyenangkan bagi anak dengan suasana kekeluargaan antara pengasuh, pengurus dan santri memang sengaja diciptakan. Tugas pengasuh selain sebagai guru yang mengajar santri juga bertugas sebagai pengganti orang tua santri. Termasuk bagi santri baru yang masuk di pondok dalam hal interaksi dan komunikasi dengan santri yang lain mereka mudah dan cepat beradaptasi. Lingkungan pondok pesantren yang ramah dan mayoritas dihuni

${ }^{21}$ Makhfud, Wawancara dengan Pengasuh Pondok Pesantren Hidayatul Mutaallimin Gurah Kediri, July 17, 2019.

22 Novi Ade Suryani, "Kemampuan Sosial Emosional Anak Melalui Permainan Raba-Raba Pada PAUD Kelompok A,” Jurnal Ilmiah Potensia 4, no. 2 (July 28, 2019): 141, https://doi.org/10.33369/jip.4.2.141150.

23 Naili Rohmah, "Bermain Dan Pemanfaatannya Dalam Perkembangan Anak Usia Dini," Tarbawi : Jurnal Pendidikan Islam 13, no. 2 (July 19, 2016): 27, https://doi.org/10.34001/tarbawi.v13i2.590. 
santri anak usia sekolah dasar mendapatkan dukungan penuh pengasuh pondok pesantren yang tidak hanya memiliki latar pendidikan agama saja beliau juga dosen sehingga paham betul bagaimana memahami psikologis anak yang jauh dari orang tua.

Ahmad Tafsir menjelaskan pengaruh lingkungan keluarga yang nyaman, suasana yang kondusif, saling pengertian, saling menyayangi dan penuh dengan kasih sayang yang membuat anak lebih bersemagat, selalu ceria dan lincah maka kecerdasan anak berkembang dengan baik. Jika suasana lingkungan tersebut terus berlanjut maka kepribadian anak umur 6-9 tahun akan tetap positif. Begitu sebaliknya perkembangan kepribadian anak menjadi negatif jika orang tua atau pengasuh sering memukul, mencela, memarahinya. Anak akan berpikir orang yang dekat dengannya saja membenci dan tidak menghargai apalagi orang lain sehingga anak akan takut bergaul dengan orang lain. $^{24}$

Kondisi psikologis dan lingkungan anak yang menetap di pondok pesantren sangat berbeda dengan mereka yang berada di asrama sekolah jika pondok pesantren memperhatikan kondisi psikologis mereka. Sebagaimana hasil penelitian menjelaskan anak usia dini dikirim ke asrama akan kehilangan ikatan emosional dasar atau primary attachments dan mengalami gangguan psikologi seperti trauma-trauma kejadian pada masa lalu saat mereka tinggal di asrama. ${ }^{25}$

Proses belajar menyesuaikan diri dengan peraturan yang berlaku, tradisi dan norma yang ada dalam lingkup kelompok dengan tetap memahami kondisi dan perasaan orang lain saat berinteraksi merupakan bagian dari proses yang positif bagi perkembangan sosial emosional anak. ${ }^{26}$ Sebagaimana yang dilakukan santri di pondok pesantren ini.

Selain lingkungan yang ramah terhadap anak, pengurus juga memberikan bimbingan dan arahan bahkan contoh kepada santri seperti cara memperlakukan dan berinteraksi sosial dengan santri baru agar betah tinggal di pondok. Jika ada santri baru yang bersedih dan menangis karena ingat rumah dan orang tua, pengurus pondok berusaha mendekati dan mengajak berkomunikasi. Cara pendekatan seperti ini ditiru oleh santri yang sudah lama menetap di pondok terhadap santri baru. Pengurus pondok

\footnotetext{
${ }^{24}$ Ahmad Tafsir, Pendidikan Agama Dalam Keluarga (Bandung: PT. Remaja Rosda Karya Offset, 2002), H. 107.

${ }^{25}$ Joy Scaverian, "Boarding School Syndrom : Broken Attachment a Hidden Trauma.," British Journal of Psychotherapy 27 (2011): h. 138-155.

${ }^{26}$ Indanah Indanah and Yulisetyaningrum Yulisetyaningrum, "Perkembangan Sosial Emosional Anak Usia Pra Sekolah,” Jurnal Ilmu Keperawatan Dan Kebidanan 10 (January 20, 2019): 222, https://doi.org/10.26751/jikk.v10i1.645.
} 
juga memberikan teladan yang baik kepada santri dalam melakukan aktifitas sehari-hari seperti menghormati guru atau orang yang lebih tua, cara bergaul dan berkomunikasi yang baik, saling memberikan dukungan antar sesama teman dan lain sebagainya. Memberikan teladan yang baik sebagaimana yang dilakukan oleh pengurus pondok ini memang bagian dari ajaran Islam dalam menyontoh dan meneladani akhlak Nabi Muhammad SAW.

Model ini sejalan dengan teori belajar sosial Albert Bandura, menurutnya anakanak akan terbentuk perilakunya dengan meniru atau menyontoh apa yang sehari-hari mereka lihat. Konsep belajar sosial akan membantu siswa membangun kecerdasan sosial, saling peduli dan menuntut partisipasi siswa. ${ }^{27}$

\section{Penutup}

Hasil penelitian menunjukkan perkembangan sosial emosional santri di Pondok Pesantren Hidayatul Muta'allimin cukup baik. Ini dapat dilihat dari berkembangnya kemampuan sosial anak dalam menjalin hubungan pertemanan dengan teman sebaya, interaksi sosial santri terjalin dengan baik, cepatnya penyesuaian diri santri dengan lingkungan tempat tinggalnya. Sedangkan perkembangan emosional santri dapat dilihat kondisi mereka yang tidak merasa kesepian atau bosan, tapi selalu terlihat gembira. Pengasuh menciptakan lingkungan pondok pesantren yang ramah bagi anak-anak, santri bebas bermain dan menonton televisi sebagai hiburan secara tidak langsung dapat membentuk jalinan komunikasi dan interaksi sosial yang positif bagi anak dengan tetap terkontrol dan diatur melalui jadwal kegiatan sehari-hari santri ada waktu khusus bermain dan belajar dapat berjalan normal tanpa muncul persoalan dan gangguan psikologis terutama perkembangan sosial emosional.

Hasil penelitian ini diharapkan menjadi bahan pertimbangan dan informasi berharga bagi orang tua yang mengirimkan anak sejak usia dini ke pondok pesantren atau memang lebih baik diasuh sendiri di rumah. Pengasuh pondok pesantren maupun tenaga pengajar diharapkan selalu memerhatikan perkembangan sosial maupun emosional santri terlebih mereka yang berusia dini, hal ini penting mengingat pada masa tersebut akan berpengaruh besar terhadap kehidupan mereka selanjutnya.

${ }^{27}$ Murni Yanto and Syaripah Syaripah, "Penerapan Teori Sosial dalam Menumbuhkan Akhlak Anak Kelas I Madrasah Ibtidaiyah Negeri 1 Rejang Lebong," TERAMPIL: Jurnal Pendidikan dan Pembelajaran Dasar 4, no. 2 (2017): 67, https://doi.org/10.24042/terampil.v4i2.2218. 


\section{Daftar Rujukan}

Alzahrani, Mona, Manal Alharbi, and Amani Alodwani. "The Effect of SocialEmotional Competence on Children Academic Achievement and Behavioral Development." International Education Studies 12 (November 29, 2019): 141. https://doi.org/10.5539/ies.v12n12p141.

Anderson, Carolynne Shinn, and Fullilove Mindy T. "The Effectiveness of Early Childhood Development Programs." American Journal of Preventive Medicine 24 (2003).

Assingkily, Muhammad Shaleh, and Mikyal Hardiyati. "Analisis Perkembangan SosialEmosional Tercapai Dan Tidak Tercapai Siswa Usia Dasar." Al-Aulad: Journal of Islamic Primary Education 2, no. 2 (July 5, 2019): 19-31. https://doi.org/10.15575/al-aulad.v2i2.5210.

Bozgün, Kayhan, and Kemal Baytemir. "Sosyal-Duygusal Ve Ahlaki Gelişim Ölçeğinin (Sdago) Türkçeye Uyarlanmasi: Geçerlik Ve Güvenirlik Çalişmasi." Adaptation of Social-Emotional and Character Development Scale Into Turkish: Validity And Reliability Study. 14, no. 1 (January 2019): 139-56. https://doi.org/10.7827/TurkishStudies.14754.

Halle, Tamara G., and Kristen E. Darling-Churchill. "Review of Measures of Social and Emotional Development." Journal of Applied Developmental Psychology 45 (July 2016): 8-18. https://doi.org/10.1016/j.appdev.2016.02.003.

Hartshorne, Timothy S., and Nancy Salem-Hartshorne. "Social/Emotional." In CHARGE Syndrome., 205-11. Genetic Syndromes and Communication Disorders Series. San Diego, CA, US: Plural Publishing Inc., 2011.

Hildayani, Rini. Psikologi Perkembangan Anak. Jakarta: Universitas Terbuka, 2011.

Hurlock, Elizabeth B. Chiled Development. Tokyo: Mc. Graw Hill. Inc, 1978.

Indanah, Indanah, and Yulisetyaningrum Yulisetyaningrum. "Perkembangan Sosial Emosional Anak Usia Pra Sekolah." Jurnal Ilmu Keperawatan Dan Kebidanan 10 (January 20, 2019): 221. https://doi.org/10.26751/jikk.v10i1.645.

Jaenudin, Ujam. Psikologi Kepribadian. Bandung: CV Pustaka Setia, 2012.

Jamin, Nunung Suryana. "Analisis Perkembangan Sosial Emosi." PEDAGOGIKA Jurnal Ilmu Pendidikan 3, no. 2 (2012).

Khoiruddin, M. Arif. "Perkembangan Anak Ditinjau Dari Kemampuan Sosial Emosional." Jurnal Pemikiran Keislaman 29, no. 2 (December 24, 2018): 425 438-425 438. https://doi.org/10.33367/tribakti.v29i2.624.

Kirk, Gill, and Jenny Jay. "Supporting Kindergarten Children's Social and Emotional Development: Examining the Synergetic Role of Environments, Play, and Relationships." Journal of Research in Childhood Education 32, no. 4 (October 2, 2018): 472-85. https://doi.org/10.1080/02568543.2018.1495671.

Makhfud. Wawancara dengan Pengasuh Pondok Pesantren Hidayatul Mutaallimin Gurah Kediri, July 17, 2019.

Malwa, Rosyidah Umpu. "Dukungan Sosial Orangtua Dengan Motivasi Belajar Siswa Putra Tahfidz Al-Qur'an.” Psikis: Jurnal Psikologi Islami 3, no. 2 (February 5, 2018): 137. https://doi.org/10.19109/psikis.v3i2.1758. 
Mayar, Farida. "Perkembangan Sosial Anak Usia Dini sebagai bibit untuk Masa Depan Bangsa." Al-Ta lim Journal 20, no. 3 (November 21, 2013): 459-64. https://doi.org/10.15548/jt.v20i3.43.

Muniroh, Siti Mumun. "Psikologi Santri Usia Dini." JURNAL PENELITIAN 11, no. 1 (January 30, 2015). https://doi.org/10.28918/jupe.v11i1.418.

Rohmah, Naili. "Bermain Dan Pemanfaatannya Dalam Perkembangan Anak Usia Dini." Tarbawi: Jurnal Pendidikan Islam 13, no. 2 (July 19, 2016). https://doi.org/10.34001/tarbawi.v13i2.590.

Scaverian, Joy. "Boarding School Syndrom : Broken Attachment a Hidden Trauma." British Journal of Psychotherapy 27 (2011).

Setyowati, Yuli. "Pola Komunikasi Keluarga dan Perkembangan Emosi Anak (Studi Kasus Penerapan Pola Komunikasi Keluarga dan Pengaruhnya terhadap Perkembangan Emosi Anak pada Keluarga Jawa).” Jurnal ILMU KOMUNIKASI 2, no. 1 (December 5, 2013). https://doi.org/10.24002/jik.v2i1.253.

Supriatna, Dedi. "Motivasi Orang Tua Memilih Pondok Pesantren Untuk Anaknya." Intizar 24, no. 1 (January 1, 1970): 1-18. https://doi.org/10.19109/intizar.v24i1.1951.

Suryani, Novi Ade. "Kemampuan Sosial Emosional Anak Melalui Permainan RabaRaba Pada PAUD Kelompok A." Jurnal Ilmiah Potensia 4, no. 2 (July 28, 2019): 141-50. https://doi.org/10.33369/jip.4.2.141-150.

Tafsir, Ahmad. Pendidikan Agama Dalam Keluarga. Bandung: PT. Remaja Rosda Karya Offset, 2002.

Wardika, I. Nyoman. "Penerapan Permainan Tradisional untuk mengatasi kejenuhan Belajar PJOK." Journal of Education Action Research 3, no. 3 (2019): 231-37. https://doi.org/10.23887/jear.v3i3.17377.

Yanto, Murni, and Syaripah Syaripah. "Penerapan Teori Sosial dalam Menumbuhkan Akhlak Anak Kelas I Madrasah Ibtidaiyah Negeri 1 Rejang Lebong." TERAMPIL: Jurnal Pendidikan dan Pembelajaran Dasar 4, no. 2 (2017): 6585. https://doi.org/10.24042/terampil.v4i2.2218. 